\begin{tabular}{|c|l|}
\hline Title & $\begin{array}{l}\text { Rapid accumulation of poly phosphate in extraradical hy phae of an arbuscular mycorrhizal fungus as revealed by } \\
\text { histochemistry and a poly phosphate kinase/uciferase sy stem }\end{array}$ \\
\hline Author(s) & Ezawa, Tatsuhiro; Cavagnaro, Timothy R.; Smith, Sally E.; Smith, F. A ndrew; Ohtomo, Ryo \\
\hline Citation & $\begin{array}{l}\text { New Phytologist, 161(2), 387-392 } \\
\text { https:/doi.org/10.1046/.1469-8137.2003.00966.x }\end{array}$ \\
\hline Issue Date & 2004 02 \\
\hline Doc URL & http://hdl.handle.net/2115/932 \\
\hline Type & article (author version) \\
\hline Note & The definitive version is available at www.blackwellsynergy.com \\
\hline
\end{tabular}

Instructions for use 


\title{
Rapid report
}

\section{Rapid accumulation of polyphosphate in extraradical hyphae of an arbuscular mycorrhizal fungus as revealed by histochemistry and a polyphosphate kinase/luciferase system}

\author{
Tatsuhiro Ezawa ${ }^{1}$, Timothy R. Cavagnaro ${ }^{2,4}$, Sally E. Smith ${ }^{2}$, F. Andrew Smith ${ }^{2}$ and Ryo Ohtomo ${ }^{3}$ \\ ${ }^{1}$ Graduate School of Bioagricultural Science, Nagoya University, Togo-cho, Aichi 470-0151 Japan; ${ }^{2}$ Soil and Land Systems, School of Earth and Environmental \\ Sciences, The University of Adelaide, SA 5005 Australia; ${ }^{3}$ National Institute of Livestock and Grassland Science, Nishi-nasuno, Tochigi 329-2793 Japan; \\ ${ }^{4}$ Present address: Department of Land, Air \& Water Resources, University of California, Davis, One Shields Avenue, Davis, CA 95616-8627, USA
}

Author for correspondence:

Tatsuhiro Ezawa

Tel: +81561370207

Fax: +81561384473

Email: tatsu@agr.nagoya-u.ac.jp

Received: 22 October 2003

Accepted: 29 October 2003

doi: 10.1046/j.1469-8137.2003.00966.x

\section{Summary}

The rate of polyphosphate accumulation in extraradical hyphae of an arbuscular mycorrhizal fungus was investigated by conventional histochemistry and a new enzymatic method using a bacterial enzyme, polyphosphate kinase. Marigold (Tagetes patula cv. Bonanza Orange) was inoculated with Archaeospora leptoticha and grown under P-deficient conditions. Extraradical hyphae were harvested at 0, 1, 3 and $24 \mathrm{~h}$ after $1 \mathrm{~mm}$ P-application. PolyP levels were assessed by both metachromasy of Toluidine blue $\mathrm{O}$ and polyphosphate kinase which converted polyP to ATP followed by the ATP-luciferase assay. Percentage of hyphae with metachromatic granules was increased from 25 to $44 \%$ from 0 to $1 \mathrm{~h}$, and a maximum of $50 \%$ was reach by $3 \mathrm{~h}$. Polyphosphate content was doubled from 1 to $3 \mathrm{~h}$ after P-application (4.8-10.0 $\mu \mathrm{mol}$ as Pi mg-1 protein) at a rate of $46.4 \pm 15.1 \mathrm{nmol} \mathrm{min}^{-1} \mathrm{mg}^{-1}$. The rate of polyphosphate accumulation in the hyphae was surprisingly rapid as those of polyphosphate-hyper accumulating microorganisms. The enzymatic method employed in the present study allows highly specific and sensitive assessment of polyphosphate in the mycorrhizal system.

Key words: arbuscular mycorrhizal fungi, luciferase, metachromasy, polyphosphate, polyphosphate kinase, Toluidine Blue O.

(C) New Phytologist (2003) 161: 387-392

\section{Introduction}

Arbuscular mycorrhizal (AM) fungi are ubiquitous and form symbiotic associations with most terrestrial plant species. It is well documented that the fungi promote growth of the host plant through enhanced uptake of phosphate. High-affinity type Pi-transporter genes have been isolated from AM fungi, and the gene products are responsible for uptake of Pi from the soil solution and into the fungal cytosol (Harrison \& Van Buuren, 1995; Maldonado-Mendoza et al., 2001). However, there is a paucity of information on the mechanisms of $\mathrm{P}$ compartmentation, translocation along hyphae and transfer from fungi to the host.
Inorganic polyphosphate (polyP) is a linear polymer of phosphate linked by high-energy bonds; a wide range of microorganisms store $\mathrm{P}$ by accumulation of polyP (Kornberg et al., 1999). It has been suggested that AM fungi accumulate polyP for long distance translocation along hyphae (Callow et al., 1978; Cox et al., 1980; Solaiman et al., 1999). However, detailed information on the dynamics of polyP turnover in AM fungi is lacking, and further research is required to elucidate the role of polyP in the P-delivery system. To this end, establishment of a specific method to quantify polyP is essential. Several colorimetiric methods for polyP measurement have been reported (Griffin et al., 1965; Allan \& Miller, 1980; Lorenz et al., 1997). Recently, metachromasy of Toluidine 
blue $\mathrm{O}$ (TBO) by polyP was applied to quantify the polyP pool in intra- and extraradical hyphae of an AM fungus, Gigaspora margariata (Solaiman et al., 1999). TBO (Ezawa et al., 2001) and 4',6-diamidino-2-phenylindole (DAPI) (Boddington \& Dodd, 1999a; Boddington \& Dodd, 1999b) were used for histochemical assessment of polyP levels in mycorrhizal hyphae. Such methods can be used for both localization and quantification of polyP. However, these stains interact with polyanionic compound such as nucleic acids. Thus, an appropriate control (e.g. nonP treatment) is required to ensure specificity and validity of the methods (Ezawa et al., 2001). In vivo ${ }^{31} \mathrm{P}$ NMR is a powerful tool to investigate polyP metabolism in mycorrhizal associations (Martin et al., 1985; Ashford et al., 1994; Gerlitz \& Werk, 1994; Martin et al., 1994; Rasmussen et al., 2000); however, this method only allows the detection of mobile (shortchain) polyP (Gerlitz \& Werk, 1994; Rasmussen et al., 2000). It is clear that each of the above methods has inherent limitations and use of such methods needs to be considered carefully.

Recently, a novel method for specific measurement of polyP using a bacterial enzyme, polyphosphate kinase (PPK), in conjunction with the ATP-luciferase assay has been developed. The method is based on conversion of polyP to ATP by PPK reverse reaction followed by chemi-luminescence assay of ATP by the luciferase system and allows highly sensitive and specific quantification of polyP (Ault-Riché et al., 1998). In the present study, we investigated polyP accumulation in Pdeficient hyphae of an AM fungus by conventional histochemistry and for the first time the PPK/luciferase method. Thus, establishing the PPK/luciferase method for AM fungi and also testing the specificity and validity of the TBO method for polyP quantification and localization.

\section{Materials and Methods}

\section{Chemicals and enzyme}

Toluidine blue $\mathrm{O}$ (TBO) and ADP (highest purity) were purchased from Sigma Chemicals and Roche Diagnotics, respectively. Polyphosphate kinase (PPK) was purified from the PPK-overexpressing Escherichia coli as described elsewhere (Ahn \& Kornberg, 1990). Specific activity of PPK after purification was $3 \times 10^{6} \mathrm{U} \mathrm{mg}^{-1}$ protein, in which $1 \mathrm{U}$ of activity was designated to phosphorylate $1 \mathrm{pmol} \mathrm{ADP} \mathrm{min}^{-1}$ at $37^{\circ} \mathrm{C}$ using polyphosphate (polyP) as a phosphoryl donor (PPK reverse reaction). Purified PPK was diluted to $3000 \mathrm{U} \mathrm{\mu l}^{-1}$ in $50 \%$ glycerol $/ 50 \mathrm{~mm}$ Tris $/ \mathrm{HCl} \mathrm{pH} 7.5$ and stored at $-20^{\circ} \mathrm{C}$.

\section{Plant and fungal materials}

Dwarf marigold (Tagetes patula L. cv. Bonanza Orange) was inoculated with c. 200 spores of Archaeospora leptoticha (Shenck $\&$ Smith) Morton \& Redecker (strain OK-15, MAFF520072) and grown on a 9: 1 river sand-soil mixture (soil $\mathrm{pH}$ was 4.9, available phosphate in the soil was less than $1.0 \mathrm{mg} \mathrm{kg}^{-1}$ ) in
$100 \mathrm{ml}$ pots $(6 \mathrm{~cm}$ in diameter $)$ in a growth chamber $(16-\mathrm{h}$ photoperiod, $\left.25^{\circ} \mathrm{C}\right)$. The plants received liquid fertilizer $+\mathrm{P}$ ( $4 \mathrm{~mm} \mathrm{NH}_{4} \mathrm{NO}_{3}, 1 \mathrm{~mm} \mathrm{~K}_{2} \mathrm{SO}_{4}, 0.75 \mathrm{~mm} \mathrm{MgSO}_{4}, 2 \mathrm{~mm} \mathrm{CaCl}_{2}$, $0.5 \mathrm{~mm}$ Fe-EDTA and $50 \mu \mathrm{M} \mathrm{KH}_{2} \mathrm{PO}_{4}$ ) for the first $4 \mathrm{wk}$ and fertilizer-P (as above minus $\mathrm{KH}_{2} \mathrm{PO}_{4}$ ) for the next week. At the 6th week, $1 \mathrm{~mm} \mathrm{KH_{2 }} \mathrm{PO}_{4}$ solution was applied to the plants, and extraradical hyphae were collected 0 (no P control), 1, 3 and $24 \mathrm{~h}$ after P-application by wet sieving followed by manipulation under a dissecting microscope. At each sampling time, hyphae were collected from three individual pots $(n=3)$. Hyphae from the same pot were divided into two subsamples: $2-3 \mathrm{mg}$ were soaked in absolute ethanol for $15 \mathrm{~min}$ (for histochemical assessment), and the remaining hyphae were frozen in liquid nitrogen and stored at $-80^{\circ} \mathrm{C}$ (for specific measurement by PPK and polyacrylamide gel-electrophoresis).

\section{Histochemical assessment by Toluidine blue $\mathrm{O}$}

The hyphae were removed from the ethanol, blotted on filter paper, stained in $0.05 \% \mathrm{TBO}$ in $50 \mathrm{~mm} \mathrm{KCl} / \mathrm{HCl} \mathrm{pH} 1.0$ for $15 \mathrm{~min}$ at room temperature, rinsed in $50 \mathrm{~mm} \mathrm{KCl} / \mathrm{HCl}$ $\mathrm{pH} 1.0$ and mounted in the same buffer on a glass microscope slide. Percentage of hyphal length showing metachromasy was assessed using a grid line intersect method as described previously (Ezawa et al., 2001).

\section{Specific measurement by polyphosphate kinase}

Five to $10 \mathrm{mg}$ hyphae were disrupted in $300 \mu \mathrm{l}$ ice-cold acetone with $c .100 \mathrm{mg}$ of zirconia beads $(0.5 \mathrm{~mm}$ in diam) by a MiniBead Beater (BIOSPEC, OK, USA) at $5000 \mathrm{rpm}$ for $3 \times 10 \mathrm{~s}$ with $1 \mathrm{~min}$ intervals on dry ice. Acetone was evaporated by vacuum centrifugation after disruption. The pellet was suspended in $400 \mu \mathrm{l}$ of the extraction buffer $(8 \mathrm{M}$ urea in $50 \mathrm{~mm}$ Tris/ $\mathrm{HCl} \mathrm{pH} \mathrm{8.0)} \mathrm{and} \mathrm{centrifuged} \mathrm{at} 20000 \times g$ for $5 \mathrm{~min}$ at $4^{\circ} \mathrm{C}$, and the supernatant was taken as the hyphal extract. Poly $\mathrm{P}$ extraction from hyphae was most efficient using $8 \mathrm{M}$ urea, however, it interfered the PPK reaction. Therefore, following polyP extraction, urea was removed by applying 50-100 $\mu \mathrm{l}$ of the extract to a Bio-Spin 6 gel-filtration column (Bio-Rad Laboratories, Tokyo, Japan). PolyP concentration was quantified using the PPK-reverse reaction (Ahn \& Kornberg, 1990) with slight modifications as follows: a PPK reaction mixture consisting of $2 \mu$ of the gel-filtrated extract, $50 \mathrm{~mm}\left(\mathrm{NH}_{4}\right)_{2} \mathrm{SO}_{4}, 4 \mathrm{~mm}$ $\mathrm{MgCl}_{2}, 40 \mu \mathrm{m}$ ADP and $600 \mathrm{U}$ PPK, $40 \mathrm{~mm}$ HEPES / KOH $\mathrm{pH} 7.5$ in a final volume of $20 \mu \mathrm{l}$ was incubated at $37^{\circ} \mathrm{C}$ for $40 \mathrm{~min}$. The reaction was terminated by heating at $95^{\circ} \mathrm{C}$ for 2 min. The mixture was diluted $1: 100$ in an ATP dilution

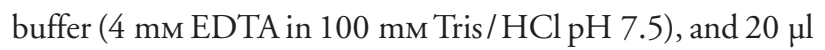
aliquots were mixed with the same volume of the luciferase reaction mixture (ATP Bioluminescence Assay Kit CLS II, Roche Diagnotics, Tokyo, Japan). Luminescence was measured as total luminescent counts in $10 \mathrm{~s}$ with a LuminescencerPSN (ATTO, Tokyo, Japan). Background ATP levels were 
determined by the PPK reaction control in which substrate (polyP) was omitted. Concentration of polyP is given in terms of Pi-residues per mg protein. Protein concentration was determined by the BCA Protein Assay Reagent Kit (PIERCE, IL, USA) using bovine serum albumin as a standard.

\section{Qualitative analysis by gel-electrophoresis}

Qualitative analysis of polyP was carried out by polyacrylamide gel-electrophoresis. Fifty to $100 \mu \mathrm{l}$ of the hyphal extract prepared from samples harvested 0 and $3 \mathrm{~h}$ after $\mathrm{P}$-application was desalted in a gel-filtration column, mixed with $1 \mu \mathrm{l}$ of $10 \mathrm{mg} \mathrm{ml}^{-1}$ ribonuclease $\mathrm{A}$ and $0.5-1.0 \mu \mathrm{l}$ of $100 \mathrm{~mm} \mathrm{BeSO}_{4}$ ( $1 \mathrm{~mm}$ in final) and incubated at $37^{\circ} \mathrm{C}$ for $1 \mathrm{~h} . \mathrm{BeSO}_{4}$ was added to inhibit hydrolysis of polyP by polyphosphatase-type enzymes in the hyphal extract (Ezawa et al., 2001). The final solutions were loaded on $10 \%$ polyacrylamide gel buffered with Tris/borate/EDTA and run at 10-20 mA constant current. Loading volume was standardized between the samples on the basis of protein concentration of crude extracts. The gel was stained with $0.05 \% \mathrm{TBO} / 25 \%$ methanol $/ 5 \%$ glycerol for $30 \mathrm{~min}$ and destained in $25 \%$ methanol $/ 5 \%$ glycerol. Chain-length of polyP was estimated based on relative mobility $\left(R_{\mathrm{m}}\right)$ to bromophenol blue, a tracking dye, according to Clark \& Wood (1987)

\section{Results}

Addition of $\mathrm{P}$ to P-deficient AM hyphae resulted in an exponential increase in $\mathrm{TBO}$ stained metachromatic granules over time. At the first harvest time ( $0 \mathrm{~h}$ after $\mathrm{P}$-application) granules were observed in c. 25\% of extraradical hyphae (Figs 1 and 2). One hour after P-application, the percentage of hyphae containing metachromatic granules increased to $44 \%$. Heavy accumulation of metachromatic granules was observed in $49-$ $50 \%$ of hyphae from 3 to $24 \mathrm{~h}$ after P-application.

Figure 3 shows polyP content in hyphae measured by the PPK/luciferase method. No increase in polyP was detected from 0 to $1 \mathrm{~h}$ after P-application (4.80 \pm 0.60 and $4.40 \pm 0.45$ $\mu \mathrm{mol} \mathrm{mg}{ }^{-1}$ protein, respectively). The polyP level increased to $9.97 \pm 1.75 \mu \mathrm{mol} \mathrm{mg}^{-1}$ at $3 \mathrm{~h}$ and was steady by $24 \mathrm{~h}$ after $\mathrm{P}$-application. The net rate of polyP accumulation from 1 to $3 \mathrm{~h}$ was calculated as $46.4 \pm 15.1 \mathrm{nmol} \mathrm{min}^{-1} \mathrm{mg}^{-1}$ protein $(P<0.05)$.

Qualitative analysis of polyP by electrophoresis clearly showed heavy accumulation of polyP $3 \mathrm{~h}$ after the $\mathrm{P}$-application (Fig. 4). Although the range of polyP chain-length was broad, there was a peak of high-molecular weight polyP around $R_{\mathrm{m}}$ 0.12 , which was estimated as more than 300 Pi-residues.

\section{Discussion}

This study provides the first information about the rate of polyP accumulation in the AM symbiosis. Using two different approaches, the maximum level of polyP was shown to occur in less than $3 \mathrm{~h}$ after P-application to hyphae growing in soil.

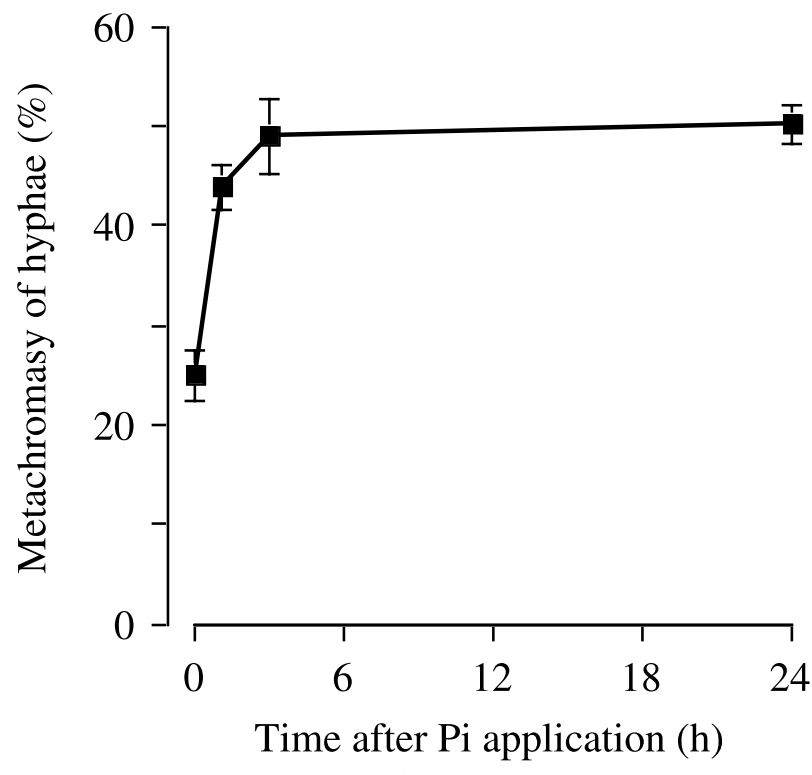

Fig. 1 Time course assessment of polyphosphate in extraradical hyphae of Archaeospora leptoticha by histochemistry. Polyphosphate was localized by metachromasy of Toluidine blue $\mathrm{O}$ and the percentage of hyphae with metachromatic granules was assessed. Vertical bars show SE $(n=3)$.
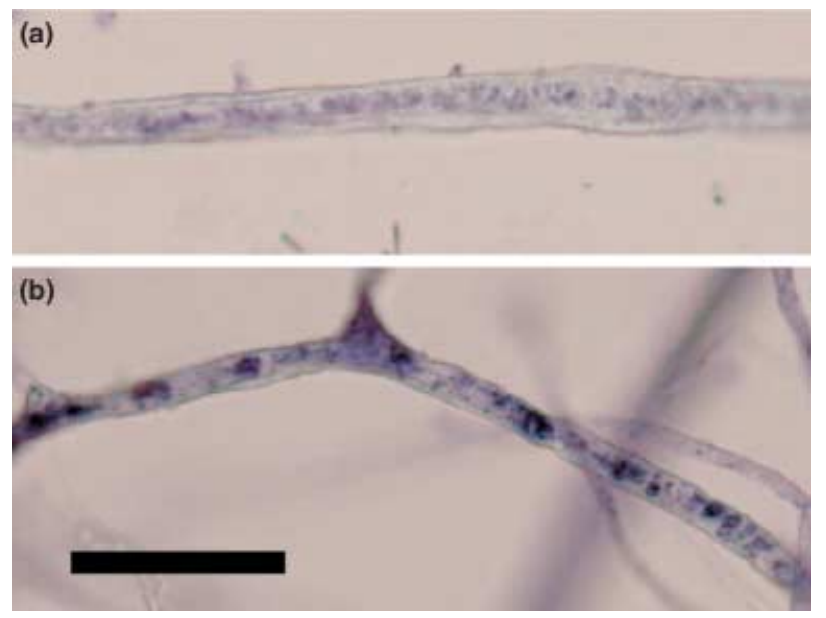

Fig. 2 Accumulation of polyphosphate in extraradical hyphae of Archaeospora leptoticha as revealed by metachromasy of Toluidine blue $O$. (a) Scattered metachromatic granules observed in hyphae harvested at zero time (no P control). (b) Heavy accumulation of metachromatic granules in hyphae harvested $3 \mathrm{~h}$ after $\mathrm{P}$-application. Bar, $10 \mu \mathrm{m}$.

PolyP accumulation in P-deficient yeast (Schuddemat et al., 1989) and bacterial cells (Castrol et al., 1999) was even more rapid and reached a maximum level within 15-30 min under glucose (energy source)-sufficient conditions. An initial polyP formation rate of Pi-deficient cells of Acinetobacter johnsonii 210 A which could accumulate polyP up to $50 \%$ of their dry weight was $98 \mathrm{nmol} \mathrm{min}^{-1} \mathrm{mg}^{-1}$ protein (van Niel et al., 1999). The rate of polyP accumulation observed in the present study

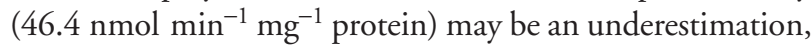




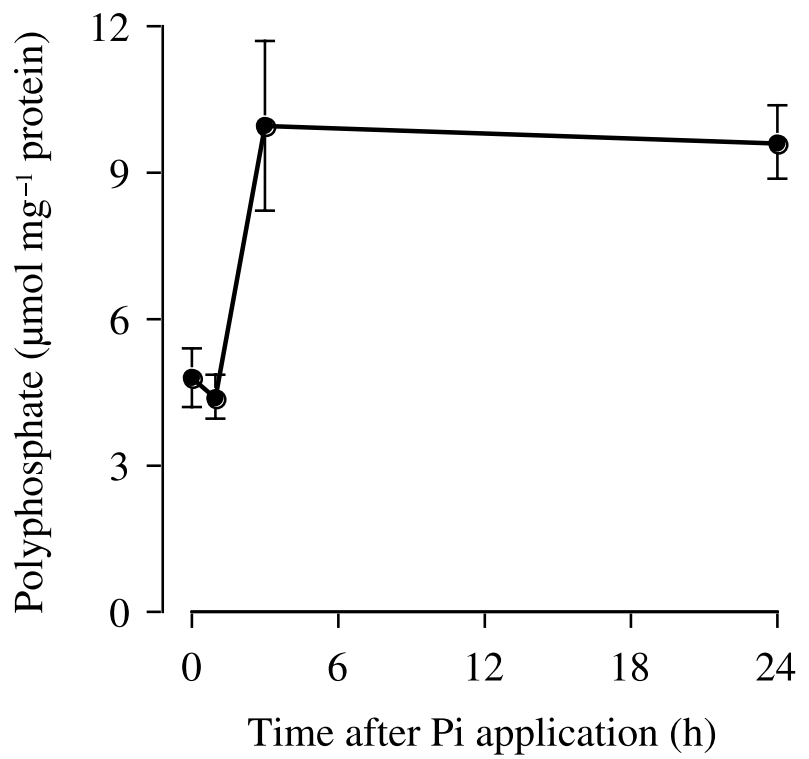

Fig. 3 Time course assessment of polyphosphate in extraradical hyphae of Archaeospora leptoticha by the polyphosphate kinase/ luciferase system. Polyphosphate was extracted and quantified as detailed in Materials and Methods, and polyphosphate content was expressed as Pi-residues per mg protein. Vertical bars show SE $(n=3)$.

because the TBO staining revealed that only $50 \%$ of extraradical hyphae were responsible for polyP biosynthesis, but the rate was calculated on the basis of total protein content of the hyphal material irrespective of the presence of polyP. Therefore, the polyP accumulation rate of the AM fungus could be comparable to that of the polyP-hyper accumulating bacteria, A. johnsonii $210 \mathrm{~A}$. It is considered that P-delivery in AM association is regulated through the following four steps: $\mathrm{P}-$ uptake, -compartmentation (polyP biosysnthesis), -translocation along hyphae and -transfer to the host. The fact that the P-uptake and subsequent polyP biosynthesis were surprisingly rapid suggests that the rate-limiting step of the P-delivery system is the translocation or transfer to the host. This hypothesis requires further confirmation.

It is predicted that external Pi concentration also affects the rate of polyP accumulation. In the present study we applied $1 \mathrm{~mm} \mathrm{Pi}$, which was extremely high compared with Pi concentration of normal soil solution. Therefore, the rate of polyP accumulation obtained in the present study can be regarded as a potential rate under optimal conditions. On the other hand, given the heterogenous distribution of nutrients in soil both spatially and temporally, our results may reflect growth of P-starved hyphae exploiting a newly created or discovered patch of nutrient rich soil.

About $50 \%$ of extraradical hyphae showed metachromatic granules using TBO in the present study, consistent with observation of Glomus coronatum with T. patula (Ezawa et al., 2001). Boddington and Dodd (1999b) observed using DAPI that $50-70 \%$ of extraradical hyphae of Gi. rosea in symbiosis with Desmodium ovalifolium accumulated polyP irrespective

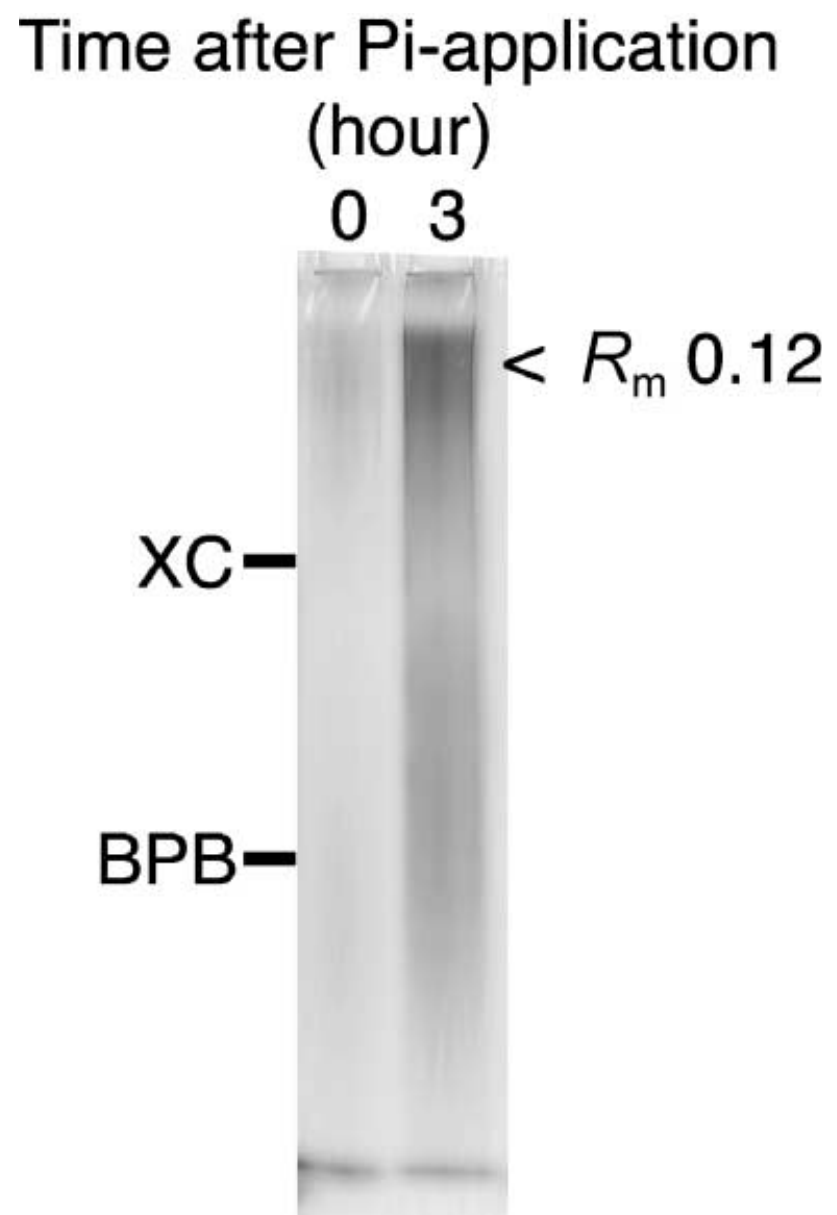

Fig. 4 Electrophoretic analysis of polyphosphate extracted from extraradical hyphae of Archaeospora leptoticha 0 and $3 \mathrm{~h}$ after $\mathrm{P}$ application. Polyphosphate was extracted, purified as detailed in Materials and Methods and loaded on $10 \%$ polyacrylamide gel (buffered with TBE). Loading volume was standardized by protein concentration of the crude extracts ( $30 \mu \mathrm{g}$ protein per lane). The position of xylene cyanol (XC) and bromophenol blue (BPB), tracking dyes of electrophoresis, are indicated. $R_{\mathrm{m}}$, relative mobility to $\mathrm{BPB}$.

of soil P fertility. The percentage of hyphae with polyP may indicate the percentage of hyphae that contribute to P-uptake and translocation in the hyphal network.

The chain-length distribution of polyP in AM fungi has not been determined precisely. An average chain-length of freely mobile polyP in Gl. intraradices was 15 as revealed by NMR (Rasmussen et al., 2000). A broad distribution of polyP chain-length was also observed in the extraradical hyphae of Gl. etunicatum in which high-molecular weight polyP was estimated as more than 190 residues (Ezawa et al., 1999). Yeast, a model eukaryotic microorganism, is known to accumulate three to several hundred Pi-residues of polyP (Kornberg et al., 1999). PolyP chain-length may depend on the balance between cell energy status (Schuddemat et al., 1989 ) and probably on P availability in environment and in turn affect solubility of polyP in situ (Ezawa et al., 2002). 
The PPK/luciferase method is highly specific and sensitive to polyP (Ault-Riché et al., 1998). This is the first case that has employed the method in AM associations. It is worthwhile that the TBO method, a conventional histochemical assessment of polyP, has been validated by the PPK method. Generally, results obtained by the TBO method were in good agreement with those obtained by the PPK method: the values at zero time were doubled at 3-24 h after P-application. The disagreement between the data at $1 \mathrm{~h}$ after P-application may be caused by the following two reasons. Firstly, we could not assess the density or size of metachromatic granules which might be less or smaller in hyphae at $1 \mathrm{~h}$ than those in hyphae at 3 and $24 \mathrm{~h}$, resulting in an overestimation of the TBOstained material at $1 \mathrm{~h}$. Secondly, sensitivity of the two methods to short-chain polyP may differ. Reactivity of PPK to polyP shorter than 20 residues is much lower than that to longer polyP, whereas $\mathrm{TBO}$ shows relatively constant reactivity to shorter polyP (T. Ezawa and R. Ohtomo, unpublished results). It has been reported that short-chain polyP was accumulated at the initial phase of polyP biosynthesis in yeast (Schuddemat et al., 1989). It is likely that the AM fungus would have accumulated short-chain polyP with which TBO could react, but PPK could not react in the first hour after P-application.

Little is known about mechanisms of polyP biosynthesis and compartmentation in eukaryotic microorganisms. Most of polyP is compartmentated in vacuoles in eukaryotic microorganisms, yeast (Kornberg et al., 1999) and Neurospora crassa (Yang et al., 1993). Rasmussen et al. (2000) suggested that polyP in AM fungi was also compartmentated in acidic compartment based on the chemical shift of terminal Pi residue of polyP by in vivo ${ }^{31} \mathrm{P}-\mathrm{NMR}$. At least two types of acidic compartment, neutral red-stained vacuoles (Ezawa et al., 2001) and tubular vacuoles (Uetake et al., 2002), are known in AM fungi, and probably there are more types (K. Saito, pers. comm.). It is expected that the techniques employed in the present study can be applied to reveal subcellular localization of polyP. Furthermore, establishment of the PPK method in conjunction with the histochemical assessment of polyP for AM hyphae extracted from a soil based system could be used as an indicator of 'nutritionally functional' AM fungi under a range of conditions.

\section{Acknowledgements}

The PPK-over expressing E. coli was a kind gift from Dr A. Kornberg (Stanford University, CA). This work was supported by the Grant-in-Aid for Scientific Research (15580048) from JSPS (TE), the Australian Research Council and the University of Adelaide (TRC, SES and FAS).

\section{References}

Ahn K, Kornberg A. 1990. Polyphosphate kinase from Escherichia coli. Purification and demonstration of a phosphoenzyme intermediate. Journal of Biological Chemistry 265: 11734-11739.
Allan R, Miller J. 1980. Influence of S-adenosylmethionine on DAPI-induced fluorescence of polyphosphate in the yeast vacuole. Canadian Journal of Microbiology 26: 912-920.

Ashford AE, Ryde S, Barrow KD. 1994. Demonstration of a short chain polyphosphate in Pisolithus tinctorius and the implications for phosphorus transport. New Phytologist 126: 239-247.

Ault-Riché D, Fraley C, Tzeng C, Kornberg A. 1998. Novel assay reveals multiple pathways regulating stress-induced accumulations of inorganic polyphosphate in Escherichia coli. Journal of Bacteriology 80: 1841-1847.

Boddington CL, Dodd JC. 1999a. A comparison of the development and metabolic activity of mycorrhizas formed by arbuscular mycorrhizal fungi from different genera on two tropical forage legumes. Mycorrhiza 8: 149-157.

Boddington CL, Dodd JC. 1999b. Evidence that differences in phosphate metabolism in mycorrhizas formed by species of Glomus and Gigaspora might be related to their life-cycle strategies. New Phytologist 142: 531-538.

Callow JA, Capaccio LCM, Parish G, Tinker PB. 1978. Detection and estimation of polyphosphate in vesicular-arbuscular mycorrhizas. New Phytologist 80: 125-134.

Castrol C, Koretsky A, Domach M. 1999. NMR-observed phosphate trafficking and polyphosphate dynamics in wild-type and $v p h 1-1$ mutant Saccharomyces cerevisiae in response to stresses. Biotechnology Progress 15 : 65-73.

Clark JE, Wood HG. 1987. Preparation of standards and determination of sizes of long-chain polyphosphates by gel electrophoresis. Analytical Biochemistry 161: 280-290.

Cox G, Moran KJ, Sanders F, Nockolds C, Tinker PB. 1980. Translocation and transfer of nutrients in vesicular-arbuscular mycorrhizas. III. Polyphosphate granules and phosphorus translocation. New Phytologist 84 : 649-659.

Ezawa T, Kuwahara S, Sakamoto K, Yoshida T, Saito M. 1999. Specific inhibitor and substrate specificity of alkaline phosphatase expressed in the symbiotic phase of the arbuscular mycorrhizal fungus, Glomus etunicatum. Mycologia 91: 636-641.

Ezawa T, Smith SE, Smith FA. 2001. Differentiation of polyphosphate metabolism between the extra- and intraradical hyphae of arbuscular mycorrhizal fungi. New Phytologist 149: 555-563.

Ezawa T, Smith SE, Smith FA. 2002. P metabolism and transport in AM fungi. Plant and Soil 244: 221-230.

Gerlitz TGM, Werk WB. 1994. Investigations on phosphate uptake and polyphosphate metabolism by mycorrhized and nonmycorrhized roots of beech and pine as investigated by in vivo ${ }^{31} \mathrm{P}-\mathrm{NMR}$. Mycorrhiza 4: 207-214.

Griffin J, Davidian N, Penniall R. 1965. Studies of phophorus metabolism by isolated nuclei. VII. Identification of polyphosphate as a product. Journal of Biological Chemistry 240: 4427-4434.

Harrison MJ, Van Buuren ML. 1995. A phosphate transporter from the mycorrhizal fungus Glomus versiforme. Nature 378: 626-629.

Kornberg A, Rao NN, Ault-Riché D. 1999. Inorganic polyphosphate: a molecule of many functions. Annual Review of Biochemistry 68: 89-125.

Lorenz B, Munkner J, Oliveira MP, Leitao JM, Muller WE, Schroder HC. 1997. A novel method for determination of inorganic polyphosphates using the fluorescent dye fura-2. Analytical Biochemistry 246: 176-184.

Maldonado-Mendoza IE, Dewbre GR, Harrison MJ. 2001. A phosphate transporter gene from the extra-radical mycelium of an arbuscular mycorrhizal fungus Glomus intraradices is regulated in response to phosphate in the environment. Molecular Plant Microbe Interactions 14: $1140-1148$.

Martin F, Marchal JP, Timinska A, Canet D. 1985. The metabolism and physical state of polyphosphate in ectomycorrhizal fungi. A ${ }^{31} \mathrm{P}$ nuclear magnetic resonance study. New Phytologist 101: 275-290.

Martin F, Rubini P, Cote R, Kottke I. 1994. Aluminium polyphosphate complexes in the mycorrhizal basidiomycete Laccaria bicolor: a ${ }^{27}$ Al-nuclear magnetic resonance study. Planta 194: 241-246. 
van Niel EWJ, de Best JH, Kets EPW, Bonting CFC, Kortstee GJJ. 1999. Polyphosphate formation by Acinetobacter johnsonii 210A: Effect of cellular energy status and phosphate-specific transport system. Applied Microbiology and Biotechnology 51: 639-646.

Rasmussen N, Lloyd DC, Ratcliffe RG, Hansen PE, Jakobsen I. 2000. ${ }^{31} \mathrm{P}$ NMR for the study of P metabolism and translocation in arbuscular mycorrhizal fungi. Plant and Soil 226: 245-253.

Schuddemat J, de Boo R, van Leeuwen CCM, van den Broek PJA, van Steveninck J. 1989. Polyphosphate synthesis in yeast. Biochimica et Biophysica Acta 1010: 191-198.
Solaiman M, Ezawa T, Kojima T, Saito M. 1999. Polyphosphates in intraradical and extraradical hyphae of an arbuscular mycorrhizal fungus, Gigaspora margarita. Applied and Environmental Microbiology 65: 5604-5606.

Uetake Y, Kojima T, Ezawa T, Saito M. 2002. Extensive tubular vacuole system in an arbuscular mycorrhizal fungus, Gigaspora margarita. New Phytologist 154: 761-768.

Yang Y, Bastos M, Chen K. 1993. Effects of osmotic stress and growth stage on cellular $\mathrm{pH}$ and polyphosphate metabolism in Neurospora crassa as studied by ${ }^{31} \mathrm{P}$ nuclear magnetic resonance spectroscopy. Biochimica et Biophysica Acta 1179: 141-147.

\section{About New Phytologist}

- New Phytologist is owned by a non-profit-making charitable trust dedicated to the promotion of plant science, facilitating projects from symposia to open access for our Tansley reviews. Complete information is available at www.newphytologist.org

- Regular papers, Letters, Research reviews, Rapid reports and Methods papers are encouraged. We are committed to rapid processing, from online submission through to publication 'as-ready' via OnlineEarly - average first decisions are just 5-6 weeks. Essential colour costs are free, and we provide 25 offprints as well as a PDF (i.e. an electronic version) for each article.

- For online summaries and ToC alerts, go to the website and click on 'Journal online'. You can take out a personal subscription to the journal for a fraction of the institutional price. Rates start at $£ 108$ in Europe/\$193 in the USA \& Canada for the online edition (click on 'Subscribe' at the website)

- If you have any questions, do get in touch with Central Office (newphytol@lancaster.ac.uk; tel +44 1524 592918) or, for a local contact in North America, the USA Office (newphytol@ornl.gov; tel 865576 5261) 